\title{
Strategi Penghidupan Ekonomi Berkelanjutan Kaum Perempuan Rumah Tangga Petani Desa Pandansari Kecamatan Ngantang Kabupaten Malang Pasca Erupsi Gunungapi Kelud Tahun 2014
}

\author{
Neni Wahyuningtyas, Agus Purnomo, dan Nurul Ratnawati
}

Masuk: 21102017 / Diterima: 29122017 / Dipublikasi: 31122017

(c) 2017 Fakultas Hukum dan IImu Sosial UNDIKSHA dan IGI

\begin{abstract}
Women in every disaster are generally only seen as passive victims and do nothing after the disaster. Whereas the role of women in disasters can have a major impact in the acceleration of postdisaster recovery efforts. The research method used in this research is qualitative. This study attempts to examine the sustainable livelihood strategies of Pandansari Village households after the eruption of Kelud 2014. Based on the research results it is known that the adaptation strategies implemented by Pandansari Village women after the eruption of Kelud in 2014 include social and economic adaptation. In social adaptation some women allocate all family members to work, another form of adaptation is with the regular gathering of citizens once a week. And in economic adaptation, some women apply job diversification to increase family income while waiting for agricultural land to be reprocessed. All forms of adaptation are an attempt to restore livelihood resources quickly.
\end{abstract}

Key words: Sustainable Livelihood Strategies, Women, Kelud

\begin{abstract}
Abstrak Perempuan dalam setiap bencana umumnya hanya dipandang sebagai korban yang pasif dan tidak melakukan apa-apa setelah bencana terjadi. Padahal peran perempuan dalam bencana dapat berpengaruh besar dalam percepatan upaya pemulihan pasca bencana. Metode penelitian yang digunakan dalam penelitian ini adalah kualitatif. Penelitian ini berupaya untuk mengkaji strategi penghidupan berkelanjutan rumah tangga masyarakat Desa Pandansari pasca erupsi Gunung api Kelud 2014. Berdasarkan hasil penelitian diketahui bahwa strategi adaptasi yang dilakukan oleh perempuan Desa Pandansari pasca erupsi Gunungapi Kelud tahun 2014 mencakup adaptasi sosial dan ekonomi. Pada adaptasi sosial beberapa perempuan mengalokasikan seluruh anggota keluarga untuk bekerja, bentuk lain dari adaptasi ini adalah dengan adanya kegiatan kumpul warga yang rutin dilakukan seminggu sekali. Dan pada adaptasi ekonomi, beberapa perempuan menerapkan diversifikasi pekerjaan untuk meningkatkan pendapatan keluarga sementara menunggu lahan pertanian dapat diolah kembali. Seluruh bentuk adaptasi tersebut merupakan upaya untuk memulihkan sumber-sumber penghidupan dengan cepat.
\end{abstract}

Kata kunci: Strategi Penghidupan, Berkelanjutan, Perempuan, Kelud

\section{Pendahuluan}

Berturut-turutnya bencana yang melanda Indonesia menyadarkan, bahwa bencana adalah bagian dari kehidupan keseharian masyarakat Indonesia yang harus disikapi dengan bijak. Respon sistematis terhadap bencana, diperlukan baik melalui disaster preparedness, tahap emergency ketika bencana terjadi, dan tahap recovery yang mencakup rekonstruksi dan rehabilitasi. Dengan melihat tahapan tersebut, pembelajaran atas respon bencana yang diikuti oleh

Neni Wahyuningtyas, Agus Purnomo dan Nurul Ratnawati Fakultas IImu Sosial Universitas Negeri Malang neni.wahyuningtyas.fis@um.ac.id,

agus.purnomo.fis@um.ac.id, nurul.ratnawati.fis@um.ac.id kebijakan untuk mengurangi risiko dan dampak bencana, juga menjadi bagian penting. Dengan disaster preparedness yang memadai misalnya, maka kebijakan tata ruang, infrastruktur dan pemukiman, hingga kepada pembangunan sosial budaya serta ekonomi menjadikan masyarakat juga menjadi siap dan sadar bila mana bencana terjadi, serta menjadikan dampak bencana menjadi lebih bisa diminimalkan.

Bencana alam pada umumnya akan berpengaruh besar dalam kehidupan 
sosial ekonomi masyarakat karena manusia hidup tidak terlepas dari alam. Salah satu bencana alam yang tidak dapat dihindari manusia adalah meletusnya gunungapi. Pada umumnya banyak kehidupan masyarakat terutama petani yang mengantungkan kehidupan seharihari pada lingkungan alam. Meletusnya gunungapi akan berpengaruh dalam kehidupan masyarakat.

Salah satunya variabel penting yang harus diperhitungkan adalah bahwa bencana yang sama bisa membawa dampak yang berbeda bagi kelompok gender yang berbeda. Sama-sama terjadi bencana banjir atau gempa misalnya, dampak yang ditimbulkan bagi laki-laki dan perempuan tidaklah identik, yang salah satunya disebabkan oleh perbedaan kerentanan terhadap bencana karena relasi gender yang ada. Laporan UN/IASC juga menuliskan bahwa struktur relasi gender adalah bagian dari konteks budaya dan sosial yang mempengaruhi kapasitas komunitas untuk mengantisipasi, menyiapkan diri, mempertahankan diri dan juga melakukan pemulihan karena bencana.

Salah satu isu kunci yang menjadi concern dari proses mentoring dalam peredaman risiko bencana ini adalah memastikan bahwa analisis gender menjadi perspektif yang terintegrasi di dalamnya. Beberapa alasan yang mendasari mengapa integrasi perspektif ini begitu penting, akan dielaborasi dalam analisis kerentanan, analisis dampak, relasi antar pihak dan pilihan-pilihan yang tersedia untuk membuat upaya antisipasi bencana menjadi lebih terkelola dengan baik. Adalah penting untuk memandang bahwa kajian gender dalam pengurangan risiko bencana berarti mendorong perempuan agar memiliki posisi kunci dalam manajemen, kepemimpinan dan juga dalam pengambilan keputusan program penangan bencana. Selain itu, karena pengurangan risiko bencana adalah bagian integral dari pembangunan, maka kajian gender dalam proses ini juga berarti upaya mendorong kesejahteraan, kesetaraan dan keadilan gender dalam pembangunan dan masyarakat.

Deklarasi Beijing dan Rencana Aksinya 1995 dengan jelas mengakui bahwa degradasi lingkungan dan bencana mempengaruhi seluruh kehidupan manusia dan seringkali membawa dampak langsung yang lebih bagi perempuan. Sessi khusus ke-23 dari General Assembly pada tahun 2000 juga mengidentifikasi bencana alam sebagai tantangan terkini yang bisa mempengaruhi implemnetasi menyeluruh dari rencana aksi Beijing ini. Karenanya, dibutuhkan strategi untuk mengintegrasikan perspektif gender dalam pengembangan dan implementasi pencegahan bencana, mitigasi dan strategi recovery.

$$
\text { Elaine Enarson } 2005 \text { (dalam }
$$
Fatimah, 2008) menjelaskan dalam tulisannya yang berjudul "Gender Equality, Work, and Disaster Reduction: Making the Connection", menjelaskan bahwa risiko terhadap bencana terdistribusikan secara berbeda di dalam masyarakat. Menurutnya, sebagai sebuah konsep yang kompleks, kerentanan dipengaruhi oleh banyak faktor. Salah satunya adalah perbedaan akses dan kontrol terhadap sumber daya, yang dibutuhkan baik untuk bertahan hidup maupun menjalani masa recovery setelah bencana. Namun, ia menggaris bawahi bahwa perempuan dan anak perempuan adalah merupakan bagian dari kelompok masyarakat yang berada pada daftar kelompok dengan risiko tinggi terhadap bencana (Earson, 2000). Sementara laporan yang dikeluarkan oleh UN/IASC pada tahun 2001 berjudul "Women, Disaster Reduction and Sustainable Development" menyebutkan bahwa perempuan menerima dampak bencana yang lebih berat. 
Gunung Kelud terletak di antara dua wilayah kabupaten di Jawa Timur, yaitu Kabupaten Kediri dan Blitar. Sebagai gunungapi yang aktif, Gunung Kelud memberikan kesuburan untuk daerah di sekitar Kelud. Maka tidak mengherankan jika dalam sebaran $7 \mathrm{~km}$ sudah terdapat banyak perkampungan penduduk (Sartohadi, 2014).

Pada bulan Januari 2014, status gunung Kelud mengalami peningkatan status. Gunung Kelud dinyatakan menunjukkan gejolak yang harus diwaspadai oleh semua pihak. Pada tanggal 13 Februari 2014 pukul 21.30 Gunung Kelud dinyatakan status Siaga I dan penduduk dalam radius $5 \mathrm{~km}$ sudah dilakukan evakuasi besar-besaran. Tidak lama kemudian pada pukul 23.20 gunung Kelud meletus (PVMBG, 2014).

Letusan tidak berlangsung lama, banyak masyarakat yang kembali ke rumah masing-masing pada tanggal 18 Februari 2014 (PVMBG, 2014). Letusan Gunung Kelud tidak menimbulkan korban jiwa di daerah Posko Pengungsian tersebut. Namun menyisakan bahaya sekundernya yaitu debu volkanik dan banjir lahar letusan. Banjir lahar letusan ini memutus di Kecamatan Ngantang dan Pujon.

Di Kecamatan Ngantang, hujan debu vulkanik itu menyebabkan rumahrumah rusak. Menurut pengungsi disana, ketebalan debu volkanik itu berkisar 10-30 $\mathrm{cm}$ di atap rumah maupun jalan raya. Setiap hari, para penyintas yang masih sehat terus membersihkan debu volkanik yang menutupi atap genteng maupun rumahnya. Sayangnya, banyak dari mereka yang tidak mempunyai alat untuk membersihkan sisa-sisa debu volkanik itu. Seperti cangkul, sekop, maupun pel. Mereka juga membutuhkan genteng ataupun asbes untuk membenarkan kembali atap rumahnya.
Pasca bencana alam Gunung Kelud, banyak aktifitas warga yang telah terkendala dan hasil produksi pertanian mengalami gagal panen. Erupsi Gunung Kelud menyebabkan kerusakan baik pada fisik, lingkungan serta sosial dan ekonomi. Dalam bencana Kelud, perempuan dan laki-laki seringkali kehilangan kapasitas untuk mempertahankan sumber penghidupan keluarganya karena hilangnya sumber penghasilan/sumber daya produksi. Meskipun laki-laki dan perempuan mengalami kerentanan yang berbeda, tetapi sebagian besar perempuan, terutama dari kalangan miskin, lanjut usia, dari kelompok minoritas sosial dan suku minoritas, memiliki strategi penanganan terbatas dan berisiko paling tinggi terkena dampak bencana alam.

\section{Metode}

Pendekatan penelitian yang digunakan dalam penelitian ini adalah penelitian yang menggunakan pendekatan kualitatif. Menurut Sugiyono (2009) mengemukakan bahwa penelitian kualitatif memandang objek sebagai sesuatu yang dinamis, hasil konstruksi pemikiran, dan interpretasi terhadap gejala yang diamati serta utuh (holistik). Hal ini dikarenakan setiap aspek dari objek itu mempunyai satu kesatuan yang tidak dapat dipisahkan, jadi realitas itu merupakan konstruksi atau interpretasi dari pemahaman terhadap semua data yang tampak di lapangan. Penelitian ini berupaya untuk mengkaji strategi penghidupan berkelanjutan rumah tangga masyarakat Desa Pandansari pasca erupsi Gunungapi Kelud tahun 2014.

Variabel yang digunakan dalam penelitian ini adalah:

a. Aspek kerentanan

b. Sumber penghidupan yang mencakup sumberdaya manusia (human capital), sumberdaya sosial (social capital), sumberdaya alam (nature capital), sumberdaya fisik (physical capital) dan 
sumberdaya keuangan (financial capital).

c. Organisasi dan kebijakan

d. Strategi penghidupan, dan

e. Capaian penghidupan

Teknik analisis data dalam penelitian ini disusun dengan mengadopsi teknik analisis data kualitiatif yang dikembangkan oleh Miles dan Huberman (1992) yaitu analisis model interaktif (interactive model of analysis). status jam $21.00 \mathrm{WIB}$, orang-orang masih menunggu dan menonton." (Warga Desa Pandansari)

Dari keterangan tersebut dapat disimpulkan bahwa Desa Pandansari tidak pernah terkena dampak dari letusan Gunungapi Kelud secara langsung yang mengakibatkan kerusakan sangat parah. Mereka juga tidak melakukan persiapan

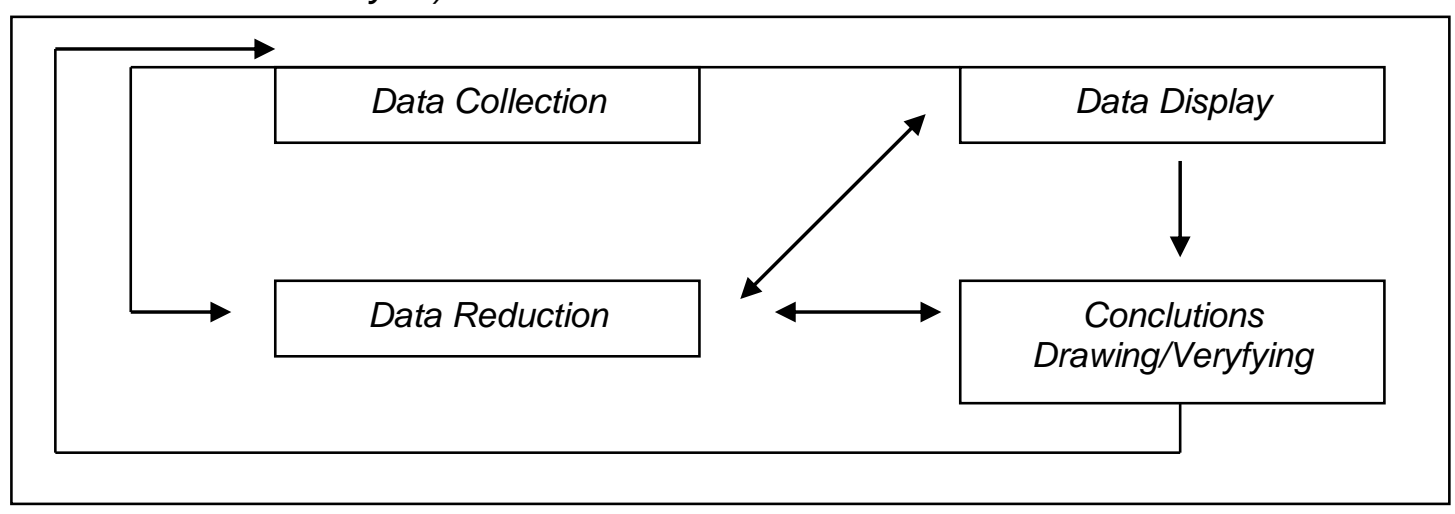

Gambar 1. Analisis Data Model Interaktif (Miles \& Huberman, 1992)

3. Hasil dan Pembahasan

\subsection{Strategi Penghidupan Rumah Tangga Keluarga Pra-erupsi Gunungapi Kelud tahun 2014}

Pada fase pra-erupsi Gunungapi Kelud tahun 2014, strategi penghidupan penduduk Desa Pandansari Kecamatan Ngantang Kabupaten Malang tidak mengalami gangguan yang berarti pada aset manusia, alamiah, fisik, finansial, dan sosial. Berdasarkan hasil wawancara dengan warga, mereka tidak menyangka jika dampak dari letusan Gunungapi Kelud akan sangat parah. Sebelum letusan tahun 2014, abu vulkanik dan/atau material letusan tidak pernah sampai ke wilayah Kabupaten Malang.

"tidak nyangka meterial sampai sini, karena dahulu-dahulunya tidak pernah kena. Letusan 1966 hanya abu, letusan tahun 1990 sini aman, tidak kena, kemarin yang tahun 2007 akan meletus tapi malah tidak jadi, nah kemudian baru tahun 2014 ini tahu-tahu arah angin ke sini. Material sampai desa, baru orang pada mengungsi. Saat peningkatan untuk mengungsi karena pada bencana sebelumnya Gunungapi Kelud tidak jadi meletus. Sehingga saat peningkatan status menjadi awas hingga meletus banyak warga panik dan tidak tahu harus berbuat apa. Seperti yang tertera pada tabel 1 diketahui bahwa saat Gunung Kelud meletus terjadi gempa vulkanik dangkal sebanyak 92 kali dan gempa vulkanik dalam sebanyak 33 kali.

Hal lain yang membuat warga panik adalah akses desa yang hanya satu pintu mengakibatkan banyak penduduk yang letak dusunnya cukup jauh dari akses utama desa kesulitan untuk mengungsi. Dari beberapa dusun yang ada, warga pada Dusun Munjung, Plumbang, dan Bales yang paling mudah untuk menyelamatkan diri. Sementara pada Dusun Klangon,Wonorejo, Sambirejo, dan Sedawun lebih sudah menyelamatkan diri. Faktor pengetahuan juga mempengaruhi tindakan yang 
dilakukan warga. Berdasarkan tabel 2 diketahui jika sejumlah 47 warga yang mengetahui titik kumpul langsung berlari melalui jalur evakuasi dan menunggu di titik evakuasi. Sementara 43 warga yang tidak mengetahui hanya berlari panik mengikuti warga yang sudah mengetahui jalur evakuasi, bahkan ada beberapa warga yang terjebak di dalam rumah.

Tabel 1 Rentang Waktu Peningkatan Status Gunungapi Kelud tahun 2014

\begin{tabular}{|c|c|c|c|}
\hline Ket Status & NORMAL & SIAGA & AWAS \\
\hline Tanggal & Kondisi Gempa & & \\
\hline \multicolumn{4}{|l|}{$2 / 02 / 2014$} \\
\hline $3 / 02 / 2014$ & & $\begin{array}{l}73 \text { kali gempa vulkanik } \\
\text { dangkal (VB), } 12 \text { kali } \\
\text { gempa vulkanik dalam } \\
\text { (VA), } 4 \text { kali gempa tektonik } \\
\text { jauh (TJ) }\end{array}$ & \\
\hline $4 / 02 / 2014$ & & 37x VB; 18x VA; 9x TJ & \\
\hline $5 / 02 / 2014$ & & 40x VB; 23x VA; 6x TJ & \\
\hline $6 / 02 / 2014$ & & $55 x$ VB; 26x VA; 4x TJ & \\
\hline $7 / 02 / 2014$ & & 117x VB; 42x VA; 2x TJ & \\
\hline $8 / 02 / 2014$ & & 152x VB; 90x VA; 11x TJ & \\
\hline $9 / 02 / 2014$ & & 157x VB; 53x VA; 5x TJ & \\
\hline 10/02/2014 & & 37x VB; 18x VA; 9x TJ & \\
\hline $11 / 02 / 2014$ & & 92x VB; 33x VA & \\
\hline \multicolumn{4}{|l|}{$12 / 02 / 2014$} \\
\hline 13/02/2014 & & & $\begin{array}{l}\text { Erupsi pukul } \\
21.15 \text { WIB }\end{array}$ \\
\hline
\end{tabular}

Sumber: Analisis Informasi PVMBG, 2014

Tabel 2 Respon Warga Desa Pandansari terhadap Bencana

\begin{tabular}{|c|c|c|}
\hline No & Respon & Jumlah \\
\hline 1 & Diam di Rumah & 18 \\
\hline 2 & Berlari menuju tempat pengungsian & 47 \\
\hline 3 & Berlari keluar dan panik & 25 \\
\hline
\end{tabular}

Sumber: Data Primer, 2015

Beberapa kelompok usia dan penduduk di Desa Pandansari juga memiliki kerentanan yang tinggi. Jumlah penduduk usia rentan mencapai 1925 jiwa, yang berarti lebih dari $30 \%$ dari keseluruhan jumlah penduduk. Kelompok usia rentan ini terdiri dari balita (0-5 tahun) sejumlah $327(7 \%)$, anak-anak (5-6 tahun) sejumlah $716(15 \%)$ dan lansia sejumlah 882 (18\%). Selain itu terdapat penduduk dengan keterbatasan fisik dan mental seperti tuna netra, wicara, grahita, dan daksa sebanyak 33 orang $(<0,5 \%$ dari jumlah penduduk total). Jadi dapat disimpulkan bahwa desa ini memiliki kerentanan demografis yang tinggi. Untuk lebih jelasnya perhatikan tabel 3 dan 4 .

Selain dari kelompok usia, sebanyak 495 Kepala Keluarga termasuk dalam kategori miskin yang termasuk kelompok rentan terhadap ancaman bencana. Dari data BKKBN sekitar 19\% dari jumlah tersebut merupakan keluarga prasejahtera yang tidak mampu untuk memenuhi kebutuhan primer (sandang, papan, pangan, pendidikan, dan kesehatan) dalam kondisi normal (tidak ada bencana). Sisanya sebanyak $>50 \%$ termasuk keluarga sejahtera tahap III dan $2 \%$ merupakan keluarga sejahtera tahap III+ yang berarti mereka dapat memenuhi kebutuhan dasar dan kebutuhan psikologis namun belum dapat memberikan kontribusi optimal terhadap masyarakat dan berpartisipasi aktif dalam masyarakat. 
Tabel 3 Kelompok Usia rentan

\begin{tabular}{llll}
\hline \multicolumn{1}{c}{ KELOMPOK USIA } & \multicolumn{1}{c}{ JUMLAH } & & PERSENTASE \\
\hline Balita (0-5 tahun) & 327 & $7 \%$ \\
Anak-anak (5-6 tahun) & 716 & $15 \%$ \\
Lansia ( $\geq 60$ tahun) & 882 & $18 \%$ \\
Total & 1925 & \\
Jumlah penduduk & 4930 & $40 \%$ dari jumlah penduduk
\end{tabular}

Sumber: BPS Kabupaten Malang, 2012, Kecamatan Ngantang dalam Angka Tahun 2011

Tabel 4 Jumlah Warga Berkebutuhan Khusus yang Tinggal di Permukiman Penduduk

\begin{tabular}{lll} 
& KELOMPOK USIA & JUMLAH \\
\hline Tuna Netra & & 4 \\
Tuna Rungu/Wicara & 4 \\
Tuna Grahita & 19 \\
Tuna Daksa & 6 \\
Jumlah & 33 \\
\hline
\end{tabular}

Sumber: BPS Kabupaten Malang, 2012, Kecamatan Ngantang dalam Angka Tahun 2011

Selain dari kelompok usia, sebanyak 495 Kepala Keluarga termasuk dalam kategori miskin yang termasuk kelompok rentan terhadap ancaman bencana. Dari data BKKBN sekitar $19 \%$ dari jumlah tersebut merupakan keluarga prasejahtera yang tidak mampu untuk memenuhi kebutuhan primer (sandang, papan, pangan, pendidikan, dan kesehatan) dalam kondisi normal (tidak ada bencana). Sisanya sebanyak $>50 \%$ termasuk keluarga sejahtera tahap III dan $2 \%$ merupakan keluarga sejahtera tahap III+ yang berarti mereka dapat memenuhi kebutuhan dasar dan kebutuhan psikologis namun belum dapat memberikan kontribusi optimal terhadap masyarakat dan berpartisipasi aktif dalam masyarakat.

\subsection{Perubahan Strategi Penghidupan Rumah Tangga Keluarga Pasca- erupsi Gunungapi Kelud tahun 2014}

Perubahan pada Aset Manusia

Aset manusia mencakup kondisi manusia sebagai seorang individu, yaitu berkaitan dengan pengetahuan, keterampilan, pendidikan, kesehatan, umur, dan jenis kelamin. Aset ini memiliki arti penting dalam kehidupan karena mendukung keberlangsungan dari penghidupan di masa mendatang/pasca bencana baik sebagai individu maupun rumah tangga. Berdasarkan hasil survai dan wawancara dengan beberapa informan disimpulkan bahwa tidak ada perubahan yang terlalu signifikan pada aset ini. Hanya pada kelompok usia yang rentan terutama lansia memiliki dampak yang cukup besar.

Kepala Dusun Munjung Desa Pandansari menjelaskan bahwa hanya satu orang warga yang meninggal sesaat setelah erupsi. Korban meninggal tersebut berusia 80 tahun dan menderita gangguan pernafasan sehingga tidak dapat ditolong. Sementara wawancara dengan beberapa warga didapatkan hasil bahwa sakit yang diderita pasca erupsi tidak terlalu berdampak dan bisa langsung disembuhkan.

Kelompok usia juga menentukan tingkat kerawanan dan perubahan pada aset ini. Pada kelompok usia anak-anak dan remaja yang sedang sekolah memiliki trauma psikologis yang cukup berat. Beberapa anak masih mengalami ketakutan hingga 3 bulan pasca erupsi dan beberapa remaja sekolah enggan untuk sekolah selama beberapa bulan 
karena hal yang sama. Ditambah lagi akses untuk ke sekolah yang rusak akibat terjangan lahar dingin sehingga untuk pergi sekolah mereka perlu menyeberang sungai yang sewaktu-waktu dapat terjadi lahar dingin saat musim penghujan. Seperti yang terlihat pada gambar 2 dimana jalan yang biasa dilewati warga tergenang lahar dingin akibat erupsi Gunung kelud. Sehingga beberapa anak masih harus diantarkan ke sekolah oleh orang tuanya.
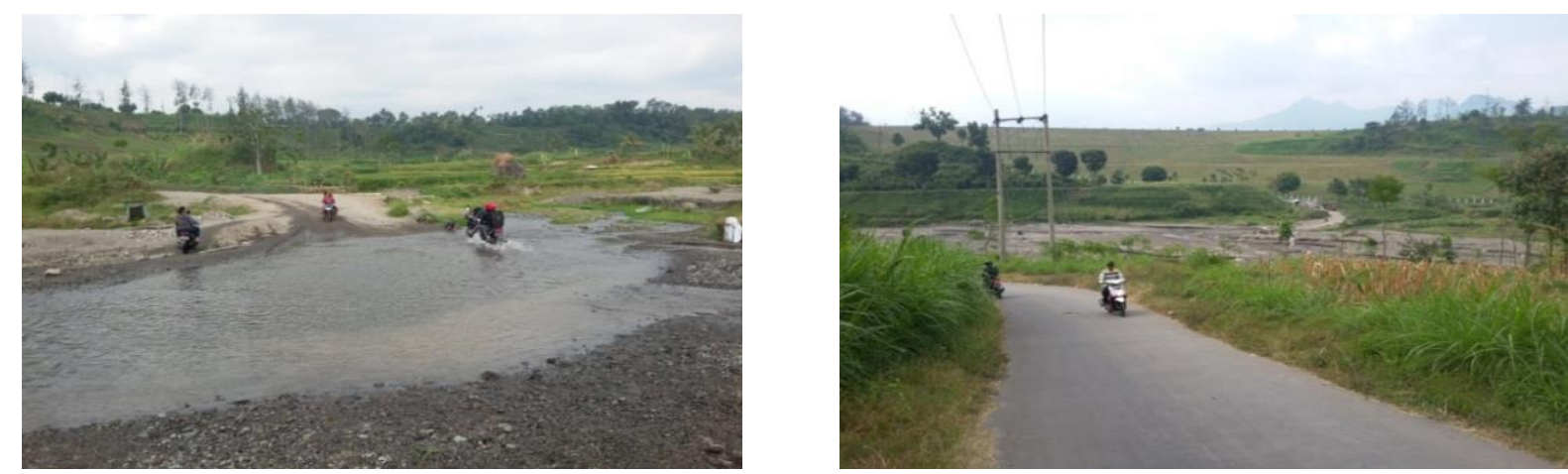

Gambar 2 Akses Jalan Keluar Desa Yang Rusak Akibat Lahar Dingin Sumber: Data Primer, 2015

\section{Perubahan pada Aset Alamiah}

Aset alamiah yang dimiliki oleh warga Desa Pandansari adalah lahan pertanian. Berdasarkan hasil survai dan wawancara, letusan tersebut mengakibatkan 94\% warga Desa Pandansari yang bekerja pada sektor pertanian dan peternakan kehilangan lahan garapan. Sebagian besar warga bekerja pada sektor pertanian dengan luas lahan yang tidak terlalu luas, rata-rata $200 \mathrm{~m} 2$ yang hasilnya untuk dikonsumsi sendiri. Selebihnya warga bekerja sebagai buruh tani (mreman dalam istilah warga Desa Pandansari) untuk mendapatkan penghasilan tambahan.

Berdasarkan wawancara dengan warga, aktifitas pertanian berhenti total pasca erupsi. Hal ini dikarenakan lahan pertanian seluruhnya tertutup oleh material erupsi baik berupa abu vulkanik maupun batuan pumice. Menurut penduduk, untuk mengembalikan lahan pertanian agar dapat ditanami kembali seperti semula memerlukan waktu beberapa minggu hingga lebih dari 1 tahun. Seperti yang terlihat di gambar 3 diketahui bahwa sampai sekarang ada beberapa lahan pertanian yang tidak dapat ditanami kembali. Warga menuturkan jika lahan yang terkena abu memiliki sifat panas sehingga benih yang ditanam akan mati. Jadi karena hal tersebut beberapa penduduk memutuskan untuk menjadi penambang pasir untuk sementara waktu hingga lahannya dapat ditanami kembali. Hal ini sesuai dengan pendapat Atmaja (2015) Arah perubahan pemanfaatan lahan sawah yang dilakukan petani tidak terlepas dari berbagai aspek yang mempengaruhinya, baik secara fisik maupun non fisik. 


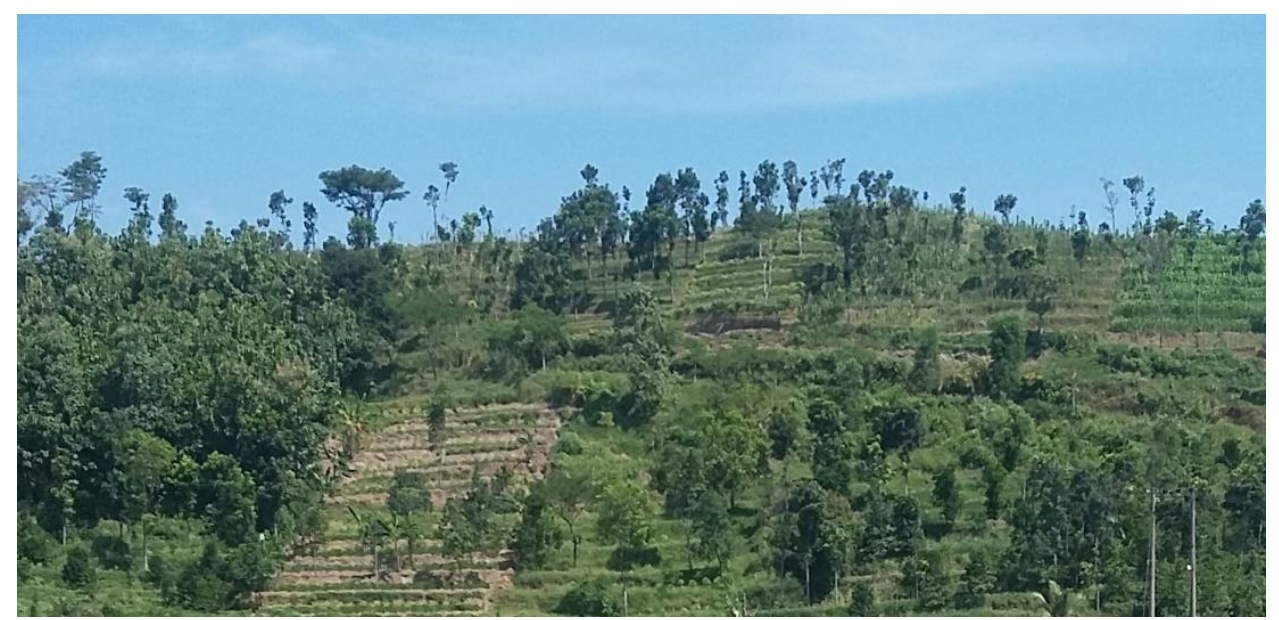

Gambar 3 Lahan Pertanian Yang Belum Dapat Ditanami Hingga Sekarang Sumber: Data Primer, 2015

Berdasarkan gambar 4 diketahui bahwa lahan persawahan milik warga tertimbun material lahar dingin dan menjadi sungai. Warga yang memiliki lahan mengalami gagal panen $100 \%$, artinya tidak ada sedikitpun dari lahan pertanian mereka yang dapat dipanen. Bahkan beberapa petani mengalami kerugian hingga $\mathrm{Rp}$. 200.000.000 karena kehilangan lahan garapan dan menjadi sungai. Sementara sebagian besar petani mengalami kerungian antara Rp. 5.000.000 sampai Rp. 25.000.000 karena kehilangan benih dan tidak dapat menanam selama beberapa waktu. warga yang sama sekali tidak memiliki lahan garapan dan bekerja sebagai buruh tani/mreman mengaku mengalami kerugian antara Rp. 1.000.000 sampai Rp. 5.000.000 karena kehilangan pekerjaan mereka untuk sementara waktu.

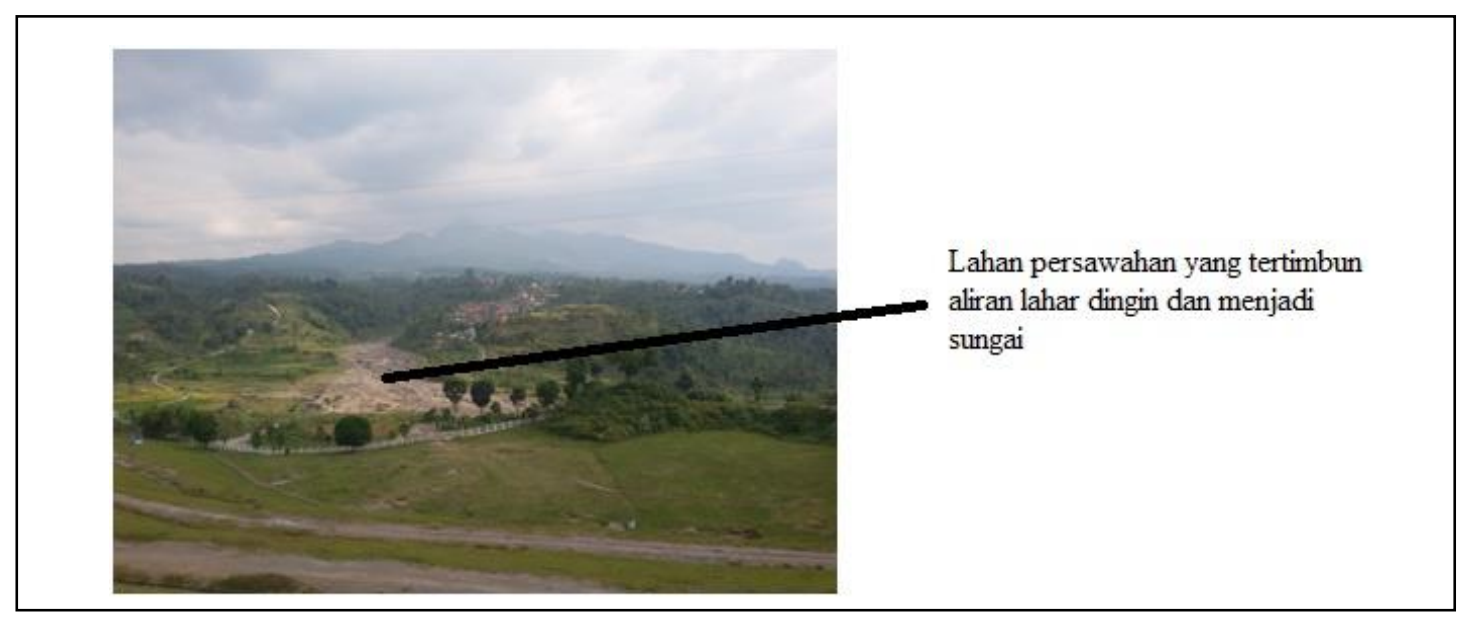

Gambar 4.

Sebagian Lahan Persawahan Yang Terkena Aliran Lahar Dingin dan Menjadi Sungai Sumber: Data Primer, 2015

Tetapi sebagian besar warga tidak merasa mengalami kerugian dari sektor pekerjaan mereka sebagai petani. Hal ini karena hasil pertanian mereka yang berupa beras 
hanya untuk dikonsumsi sendiri. Saat terjadi erupsi bantuan berupa bahan makanan datang mengalir sehingga pemikiran kehilangan harta benda yang berasal dari hasil pertanian ada gantinya. Dari hasil penelitian diketahui jika bantuan terus mengalir hingga 3 bulan pasca erupsi Bantuan tersebut berupa air bersih, bahan makanan dan bahan bangunan.

\section{Perubahan pada Aset Finansial}

Erupsi Gunungapi Kelud tanggal 13 februari 2014 memberikan dampak finansial yang cukup signifikan. Hujan abu vulkanik dan pumice menyebabkan gagal panen. Kegagalan panen berarti kerugian yang sangat besar bagi petani, karena mereka kehilangan modal tanam berupa benih dan obat-obatan serta biaya perawatan dan biaya sewa lahan. Pada umumnya modal yang digunakan merupakan modal pinjaman dari bank yang harus segera dikembalikan.

Pada fase pasca erupsi, penduduk yang bermata pencaharian sebagai petani masih belum memiliki modal untuk dapat memulai aktivitas kembali. Petani yang hewan ternaknya selamat pada masa pasca erupsi mengalami kesulitan dalam mencari pakan ternak karena hujan abu vulkanik dan pumice mematikan seluruh vegetasi yang ada. Jadi karena itu warga yang ternaknya dapat diselamatkan memilih untuk menjual ternak sebagai modal awal usahanya. Tetapi rusaknya lahan pertanian mengakibatkan banyak petani yang membutuhkan modal tambahan untuk memulihkan lahannya. Atas dasar itu tidak sedikit petani yang memilih untuk berpindah menjadi penggali pasir sementara menunggu lahannya pulih kembali.

Bantuan pada fase pasca erupsi terus berdatangan. Warga yang telah memiliki pinjaman sebelumnya kepada pihak bank diberikan bantuan modal usaha berbunga rendah secara cumacuma untuk memulai usahanya kembali. Petani juga mendapatkan bantuan berupa benih dan obat-obatan. Dari pemerintah daerah serta dinas peternakan memberikan bantuan berupa indukan sapi perah yang produktif.

\section{Perubahan pada Aset Fisik}

Perubahan pada aset fisik paling besar dirasakan oleh Desa Pandansari Kecamatan Ngantang Kabupaten Malang. Kerusakan bangunan paling utama terdapat pada atap rumah yang hancur karena lontaran material vulkanik. Banyak warga tidak sempat menyelamatkan harta benda sehingga sebagian besar furnitur dan perabotan rusak parah.

Berdasarkan wawancara dengan beberapa informan, mereka tidak menyangka erupsi akan separah itu dan hanya mengamankan barang-barang seperti perabot di bawah kasur. Ternyata setelah 4 hari mengungsi dan diperbolehkan pulang mereka mendapati tumahnya (rumahnya) telah rata dengan tanah. Seperti yang terlihat pada gambar 5 diketahui bagaimana kondisi rumah warga yang luluh lantah akibat erupsi Gunung Kelud.

\begin{tabular}{lrrr}
\multicolumn{2}{c}{ Berdasarkan } & hal & tersebut \\
pemerintah & Provinsi & Jawa & Timur \\
memutuskan & untuk & membantu
\end{tabular}
memperbaiki rumah warga yang rusak bekerja sama dengan Kodam $\mathrm{V}$ Brawijaya sebagai pelaksana proses rehabilitasi dan rekonstruksi. Semua penduduk yang rumahnya rusak diberi tanda untuk kemudian diperbaiki oleh anggota TNI sesuai nomor urut. Bentuk kerusakan yang sama, yaitu pada atap rumah mengakibatkan peningkatan kebutuhan genting sehingga menghambat proses rehabilitasi karena pasokan yang terbatas. Namun demikian tidak semua warga 
hanya menunggu bantuan TNI dan relawan, sebagian warga yang rumahnya tidak rusak terlalu parah memilih untuk membenahi rumahnya sendiri.

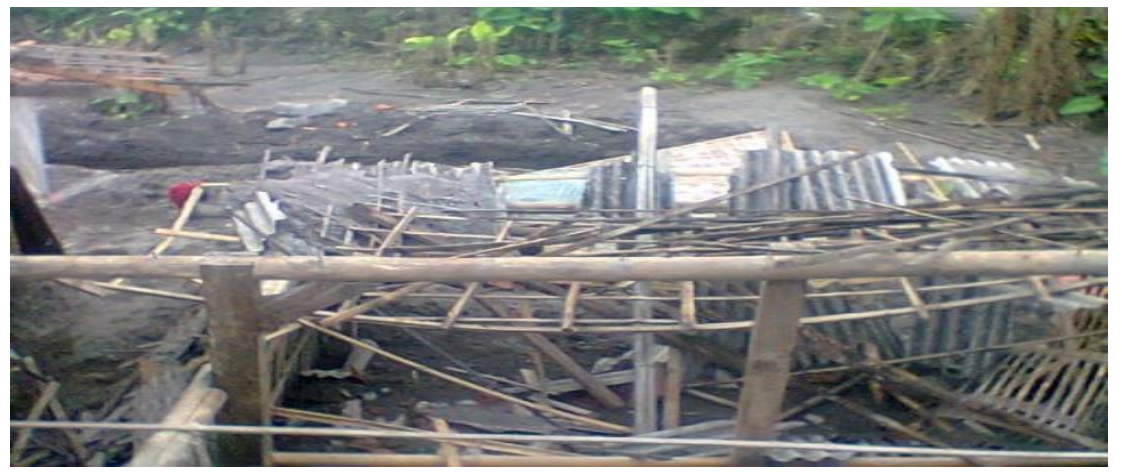

Gambar 5 Kerusakan Bangunan Akibat Erupsi Gunungapi Kelud Sumber: Data Sekunder Dari Informan, 2015

Proses pemberian bantuan dari pihak TNI dan relawan menurut warga dirasakan tidak memikirkan faktor psikologis korban bencana yang sedang berada di pengungsian. Pasalnya warga mendapatkan informasi bahwa jika saat pendataan tidak ada perwakilan maka rumah yang rusak tersebut tidak direnovasi. Padahal mereka di pengungsian masih mengalami trauma. Selain itu proses pemberian bantuan yang tidak satu pintu mengakibatkan adanya kecemburuan sosial, karena pemberian bantuan yang tidak merata.

Proses rehabilitasi dan rekonstruksi rumah warga awalnya berlangsung lambat dan terkesan warga seperti lebih menunggu bantuan dari TNI dan relawan. Selain kendala berasal dari akses utama masuk ke Desa Pandansari yang terputus karena lahar dingin, warga mengaku masih trauma dan kurang siap menghadapi erupsi Gunungapi Kelud tahun 2014.

Selain merusak rumah warga, fasilitas-fasilitas publik juga ikut rusak. Pusat pendidikan dan pusat kesehatan berupa polindes ikut rusak parah dan perlu dibangun ulang. Pusat pendidikan berupa Sekolah Dasar (SDN) Pandansari tidak mengalami kerusakan yang parah, hanya bagian atap yang roboh, sementara strukturnya masih kokoh sehingga tidak perlu dibangun ulang. Lain dengan Polindes yang hancur dan terbakar sehingga perlu dibangun ulang. Tetapi karena petugas kesehatan yang bukan penduduk asli Desa Pandansari mengakibatkan layanan kesehatan tidak selalu ada setiap saat. Petugas kesehatan yang rumahnya di Kecamatan Pujon selalu datang saat pagi hari dan pulang sebelum sore karena takut jika terjadi lahar dingin akan terjebak dan tidak bisa pulang ke rumah.

\section{Perubahan pada Aset Sosial}

Aset sosial erat kaitannya dengan hubungan sosial masyarakat baik dalam masyarakat itu sendiri maupun dengan pihak luar. Berdasarkan wawancara dan hasil survai di Desa Pandansari menunjukkan bahwa terdapat hubungan yang baik antar warga. Hal ini dibuktikan dengan adanya dua kegiatan pertemuan rutin warga dalam bentuk tahlil dan PKK. Pada masa pra erupsi tahlil dan PKK biasanya dilakukan seminggu sekali dan dilakukan bergilir dari rumah satu warga ke rumah lainnya. Bahkan saat pasca 
erupsi kegiatan tahlil tetap dilakukan dengan cara yang sama.

Saat fase erupsi hubungan antar warga semakin terjalin erat. Seperti yang terlihat pada gambar 6 , tradisi gotong royong untuk membersihkan dan memperbaiki rumah warga dilakukan bersama-sama.
Perbaikian dilakukan bergiliran dari rumah ke rumah sesuai dengan urutan yang telah ditentukan. Masing-masing rumah mendapatkan giliran untuk diperbaiki dan mendapatkan bantuan genting sesuai dengan kebutuhan perbaikan rumah mereka.

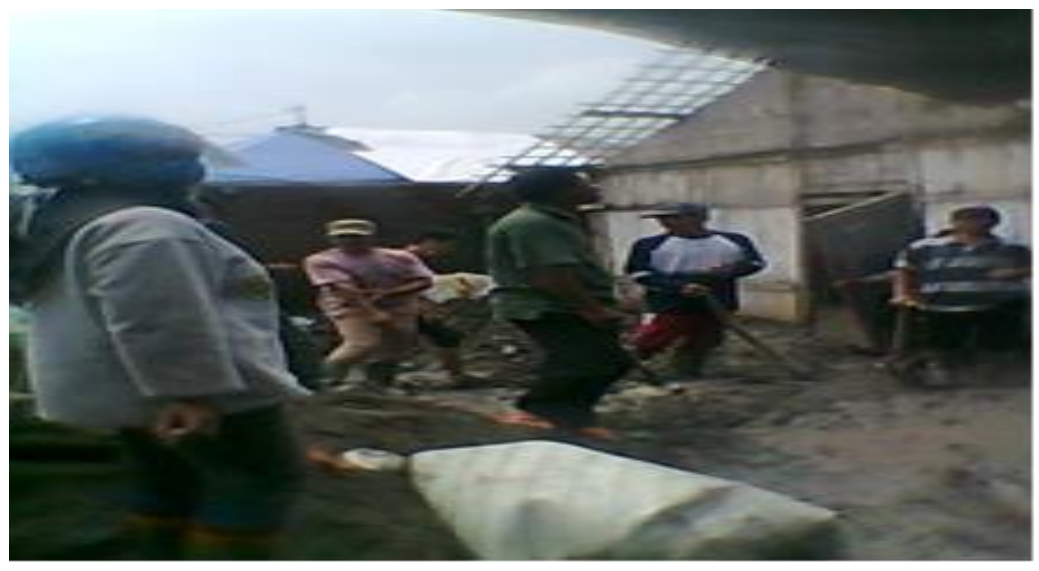

Gambar 6. Warga Saling Membantu Untuk Saling Memperbaiki Rumah Sumber: Data Sekunder Dari Informan, 2015

Warga juga merespon baik setiap bantuan yang datang ke Desa Pandansari. Warga tidak merasa terganggu dengan adanya warga dari luar desa yang datang hanya untuk menonton, karena mereka hanya menonton pada batas desa. Warga luar yang datang untuk menonton tertarik pada aliran lahar dingin yang tiba-tiba terbentuk dan memutuskan akses masuk ke desa. Jadi secara tidak langsung sulitnya akses masuk ke desa membuat warga luar yang tidak berkepentingan tidak bisa masuk.

\subsection{Analisis Peran Perempuan dalam Strategi Penghidupan Berkelanjutan sebagai Bentuk Adaptasi Pasca Erupsi Gunungapi Kelud 2014}

Perempuan merupakan salah satu aktor yang sangat penting dalam proses rekonstruksi dan rehabilitasi pasca bencana, namun dalam beberapa aspek kajian ataupun program-program pasca bencana mereka tidak banyak dilibatkan. Kondisi demikian telah dianggap sebagai hal yang lumrah karena dalam budaya Jawa, wanita telah lama dikonstruksikan secara sosial maupun budaya untuk menjadi "kanca wingking" (Wanita dikonstruksikan hanya berkutat pada berbagai urusan rumah tangga dan geraknya pun dibatasi dalam lingkup rumah tangga) (Nugraheni S, 2012). Mereka umumnya dipandang sebagai korban yang pasif dalam programprogram pasca bencana. Pada kenyataannya perempuan memiliki peran yang cukup penting dalam mengatur perekonomian keluarga atau membuat membuat keputusan yang penting. Salah satu informan (Isah, 31) memberikan keterangan untuk meminta suaminya pergi keluar negeri menjadi TKI setelah pasca erupsi Gunungapi Kelud tahun 2014 terjadi. 
"Ya mau bagaimana lagi, jika tetap bertahan dengan pekerjaan yang lama (buruh tani/mreman) tidak ada penghasilan sekarang. Dulu bapak pernah jadi TKI dan bisa membangun rumah dibelakang itu, tapi sekarang sudah hancur dan tidak ada lagi sisanya. Rumah yang baru ini ya hasil dari bapak kerja jadi TKI selama 1tahun".

Kenyataan tersebut menyangkal bahwa perempuan merupakan korban bencana yang pasif. Salah satu bukti ini menunjukkan hal yang sebaliknya. Perempuan dapat menjalankan perannya seperti biasanya bahkan lebih dari pria yang pada beberapa kasus pasca bencana menunjukkan sikap yang tanggap dan cenderung aktif (Chew dan Ramdas, 2005). Beberapa hasil wawancara menunjukkan ada beberapa ibu rumah tangga yang membuat keputusan untuk menjual ternaknya agar dapat dijadikan modal usaha atau meminta kepada suami untuk bekerja di penggalian pasir untuk sementara waktu. Mereka mempunyai pemikiran bahwa lahan yang terdampak erupsi Gunungapi Kelud akan membutuhkan waktu yang lama dan biaya yang tidak sedikit untuk dapat ditanami kembali. Selain itu bantuan dari pemerintah hanya sebatas pada pemberian benih dan induk sapi bagi kelompok-kelompok petani, namun tidak ada upaya untuk pemulihan lahan garapan sehingga ada beberapa petani yang tidak memiliki modal terpaksa untuk membiarkan lahannya tidak ditanami sementara waktu dan bekerja pada sektor lain.

Meski ada beberapa wanita yang
dapat berperan dalam membantu pemulihan pasca erupsi, ada beberapa wanita yang memilih untuk diam dan pasrah kepada nasib. Mereka dimanjakan oleh bantuan yang terus mengalir. Dari hasil wawancara mereka tidak melakukan kegiatan seperti biasanya karena kebingunan dan masih trauma. Mereka kebingungan harus melakukan apa, untuk bekerja lahan pertanian yang ada sudah rusak dan membersihkan rumah juga tidak bisa karena sebagian besar atap rumah roboh dan semua perabot di dalamnya rusak.

Strategi adaptasi yang dilakukan setiap wanita berbeda-beda. Adapun beberapa strategi tersebut adalah strategi sosial yang meliputi mengalokasikan seluruh keluarga untuk bekerja dan meningkatkan pendapatan keluarga. Seperti yang dilakukan pada Bu Rusiatin (42) yang memiliki anggota keluarga sebanyak 4 orang. Sebelum erupsi 4 anggota keluarga yang masih menjadi tanggungan tidak bekerja, mereka hanya sesekali saja datang membantu ke sawah ketika panen tiba. Tetapi pada fase pasca erupsi $\mathrm{Bu}$ Rusiatin mengajak seluruh anggota keluarganya untuk menjadi buruh tani/mreman yang upah seharinya bisa mencapai Rp. 25.000 jika mereka bekerja penuh seharian dari pagi hingga tengah hari. Jadi bila sebelumnya bila keluarga ini hanya mendapatkan penghasilan rata-rata Rp. 50.000 perhari kini dengan tambahan 4 orang pekerja keluarga ini mendapatkan tambahan penghasilan sebanyak $R p$. 100.000 per hari. Dengan adanya tambahan pengahasilan ini diharapkan dapat memulihkan perekonomian keluarga dengan cepat.

Tidak seluruh warga Desa Pandansari menerapkan strategi adaptasi sosial yang mengalokasikan seluruh anggota keluarga untuk bekerja. Bu Sumiati (60) yang memiliki anggota keluarga sebanyak 3 orang tidak melakukan hal tersebut. Alasannya mereka masih baru lulus sekolah dan masih mengalami trauma sehingga kalau diajak bekerja masih seperti orang yang kebingungan. 
Strategi adaptasi sosial juga dilakukan dengan rutin mengadakan kegiatan kumpul warga yang rutin dilakukan setiap minggunya. Dari hasil survai dan wawancara kegiatan tersebut berupa tahlil dan PKK. Kegiatan ini merupakan kegiatan yang sudah rutin dilakukan jauh sebelum erupsi terjadi. Tetapi pada fase pasca erupsi, kepala desa berpendapat jika kegiatan ini perlu untuk terus diadakan guna memberikan kegiatan warga pasca erupsi sekaligus untuk memulihkan kondisi psikologis yang baru mengalami trauma.
Yang berbeda adalah pada fase sebelum erupsi tidak pernah dibahas tentang mitigasi bencana pada kegiatan tahlil dan PKK. Tetapi pada fase pasca erupsi dua kegiatan tersebut mulai membahas hal-hal yang harus dilakukan dan disiapkan saat bencana terjadi. Seperti yang terlihat pada gambar 7, terdapat ruang kesekretariatan gradasi desa mitigasi yang berada di sebelah kantor desa. Ruang ini dijadikan sebagai pusat informasi dan kegiatan terkait mitigasi bencana di Desa Pandansari untuk mendukung kegiatan sosial tersebut.

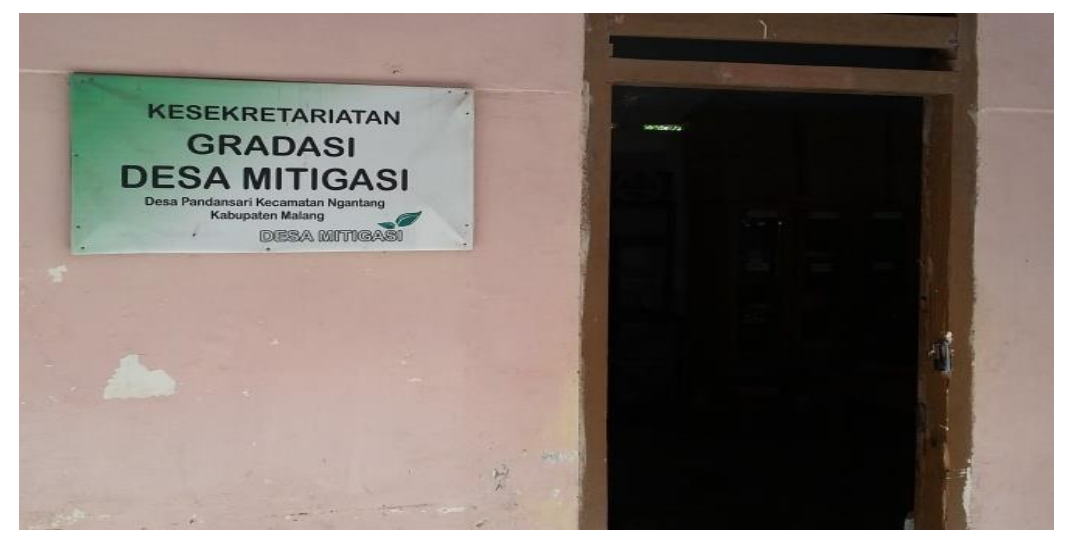

Gambar 7 Pusat Kegiatan Mitigasi Bencana Desa Pandansari Sumber: Data Primer, 2015

Strategi adaptasi ekonomi yang dilakukan oleh perempuan Desa Pandansari meliputi diversifikasi pekerjaan. Beberapa perempuan memutuskan agar suaminya bekerja pada sektor yang berbeda selama menunggu lahan pertanian dapat ditanami kembali. Sektor-sektor tersebut adalah pertambangan (galian pasir), konstruksi (buruh bangunan), dan industri (buruh pabrik). Sektor pertambangan adalah sektor yang paling banyak. Sebagian besar petani yang kehilangan lahan garapan karena banjir lahar dingin Sungai Konto beralih menjadi penambang pasir. Beberapa penambang pasir ini bekerja atas dasar rekomendasi istrinya dan sebagian lain merupakan kesadaran diri sendiri untuk mencari nafkah dengan cepat. Petani yang bekerja di penambangan pasir mengaku memiliki penghasilkan yang cukup untuk hidup sehari-hari. Penghasilan dari tambang pasir diperoleh dengan cara mengumpulkan 1 truk pasir (1 rit) yang jumlahnya setara dengan 6-8 kubik, baik sendiri atau berkelompok. Hasil tersebut kemudian dijual dan dibagi rata sesuai dengan jumlah penambang. Harga 1 truk pasir dapat mencapai Rp. 250.000 - 300.000.

Strategi adaptasi ekonomi yang lain adalah penghematan pengeluaran. 
Bencana erupsi Gunungapi Kelud telah menggugah banyak pihak untuk membantu warga Desa Pandansari yang menjadi korban. Bantuan terus berdatangan baik dari pihak pemerintah dan swasta. Bantuan tersebut berupa bahan makanan, obatobatan, pakaian, modal usaha, dan bahan bangunan. Bantuan-bantuan tersebut memberikan kesempatan bagi korban untuk menghemat pengeluaran sementara waktu sehingga memberi untuk memulihkan kondisi ekonomi keluarga. Bahan makanan serta air bersih masih datang sampai 3 bulan pasca bencana sehingga warga merasa sangat terbantu selama masa rekonstruksi dan rehabilitasi pasca bencana.

Dari hasil survai dan wawancara strategi adaptasi yang dilakukan oleh perempuan dipengaruhi beberapa faktor, yaitu tingkat pendidikan dan jumlah anggota keluarga. Perempuan yang memiliki pendidikan lebih tinggi akan mempunyai pemikiran yang lebih logis dalam menjalankan perannya menjalankan keberlangsungan rumah tangga. Seperti Isah (31) yang memiliki pendidikan SMA menyarankan suaminya untuk pergi ke luar negeri menjadi TKI. Dari hasil survai dan wawancara perempuan dengan pendidikan yang lebih tinggi dari SMP, mencari pekerjaan lain seperti menjadi penjahit dan ikut suami kerja di kota sebagai buruh pabrik. Sementara perempuan lainnya dengan pendidikan rata-rata SD memilih untuk diam di pengungsian dan pasrah terhadap apa yang akan dikerjakan suaminya atau kepala keluarga dan setelah lahan pertanian dapat ditanami mereka kembali bekerja sebagai petani atau buruh tani/mreman.

$$
\text { Semakin banyak jumlah }
$$

anggota keluarga berarti semakin banyak tanggungan yang ada dan kondisi tersebut akan berdampak pada kebutuhan pokok. Jumlah anggota keluarga juga mempengaruhi adanya keterlibatan anggota keluarga lain dalam mencari nafkah, dalam hal ini para istri membantu suaminya dalam mencari nafkah. Semakin banyak jumlah orang yang tinggal dalam satu rumah tangga akan mengakibatkan beban ekonomi di keluarga cukup tinggi jadi tidak mungkin jika hanya satu orang saja yang bekerja untuk memenuhi kebutuhan ekonomi rumah tangga. Strategi adaptasi yang dilakukan oleh perempuan pada fase pasca bencana erupsi Gunungapi Kelud adalah dengan ikut membantu suami bekerja.

\section{Penutup}

Strategi adaptasi yang
dilakukan oleh perempuan Desa
Pandansari pasca erupsi Gunungapi Kelud tahun 2014 mencakup adaptasi sosial dan ekonomi. Adaptasi sosial diwujudkan dengan adanya beberapa perempuan yang mengalokasikan seluruh anggota keluarga untuk bekerja. Bentuk lain dari adaptasi ini adalah dengan adanya kegiatan kumpul warga yang rutin dilakukan seminggu sekali seperti tahlilan. Sedangkan adaptasi ekonomi diwujudkan dengan adanya beberapa perempuan yang menerapkan diversifikasi pekerjaan untuk meningkatkan pendapatan keluarga.

Seluruh bentuk adaptasi yang dilakukan oleh kaum perempuan di 
Desa Pandansari tersebut merupakan upaya untuk memulihkan sumbersumber penghidupan dengan cepat. Bentuk-bentuk adaptasi yang dilakukan tidak serta-merta dilakukan oleh seluruh perempuan Desa Pandansari. Hal tersebut dipengaruhi oleh beberapa faktor, antara lain tingkat pendidikan dan jumlah anggota keluarga.

\section{Daftar Pustaka}

Arikunto, S. (2006). Prosedur Penelitian Suatu Pendekatan Praktik. Jakarta: PT Rineka Cipta

Atmaja, Dewa Made. (2015). Dampak Strategi Petani Dalam Merubah Arah Pemanfaatan Lahan Sawah Terhadap Kenyamanan Hidup Di Kota Denpasar. Media Komunikasi Geografi,16(1).

Badan Geologi Kementrian ESDM. (2014). Status Gunungapi Kelud. dipublikasikan htp://www.vsi.esdm.go.id/index. php/ gunungapi/aktivitasgunungapi/informasi-g-kelud (diakses 1 Maret 2015).

Cain, M, and McNicoll, G. (1988). Population growth and agrarian outcomes. in R.D. Lee et al. (eds). Population, Food and Rural Development. Oxford: Clarendon

Chew, L. dan K. N. Ramdas. (2005). Caught in the Storm: The IImpact of Natural Disasters on Women. The Global Fund for Women.

Chhotray, V. and Few, R. (2012). Postdisaster recovery and ongoing vulnerability: Ten years after thesuper-cyclone of 1999 in Orissa, India. Global
Environmental Change, 22: 695702.

Cutter, L.S., Barnes, L., Berry, M., Burton, C., Evans, E., Tate, E. and Webb, J., (2008). A placebased model for understanding community resilience to natural disasters. Global Environmental Change, 18(4): 598-606.

Enarson, Elaine. (2004). International Perspectives on Gender and Disaster. Differences and Possibilities. 24(11): 49-93.

Enarson. (2000). Women's Voluntary Work Expands : Gender Equality, Work and Disaster Reduction : Making The Connection. revised version of Gender and Natural Disasters, Working Paper \# 1 (September, 2000) prepared for the ILO In Focus Programme on Crisis Response and Reconstruction, USA.

Fatimahh, Dati. (2008). Gender Mainstreaming dalam Pengurangan Resiko Bencana. Yogyakarta: Circle Indonesia HIVOS.

Lindell, M.K. and Prater, C.S., (2003). Assessing Community Impacts of Natural Disasters. Natural Hazards Review, 4: 176 - 185.

Miles, M.B., \& Huberman, A.M. (1992). Qualitative Data Analysis: an Expanded Source Book. Thousant Oaks CA: Sage Publication Inc.

Nugraheni S, Wahyu. (2012). Peran dan Potensi Wanita dalam Pemenuhan Kebutuhan Ekonomi Keluarga Nelayan. Journal of Educational Sosial Studies (JESS), 1(2): 104-111. 
Sartohadi, Junun. (2014). Pengelolaan Bencana Kegunungapian Kelud pada Periode Krisis Erupsi 2014. Yogyakarta: UGM Press.

Sugiyono. (2009). Metode Penelitian Kuantitatif, Kualitatif, Dan $R \& D$. Bandung: CV Alfabeta

Sutopo. (2006). Metode Penelitian Kualitatif. Surakarta. UNS Press.

Widyatmoko, M. R. Djarot Sidharto. (2012). Analisis Risiko Dampak Erupsi Gunungapi Merapi Terhadap Penghidupan Petani Salak di Kabupaten Sleman dalam Kerapi. Kajian Multidisiplin, (eds) Hartono, dkk. Yogyakarta: Penerbit Sekolah Pascasarjana UGM.

Wisner, B., Blakilie, P., Canon, T. and Davis, I., (2004). At Risk: Natural Hazards, People's Vulnerability and Disasters. New York: Routledge. 